\title{
REPRESENTATION OF THE CONSUMER INTEREST IN THE FEDERAL GOVERNMENT
}

\author{
SAUL NeLSON*
}

\section{The Nature of the Consumer Interest}

Reorganization of the executive departments looms as the largest single piece of unfinished business confronting the 1939 Congress. Among the more significant proposals which have been discussed, is the establishment of a Consumers' Bureau under a Department of Public Welfare. Strong pressure for such action is being exerted from many sources. There seems to be general agreement that the interests of the consumer are not adequately represented in the process of government, though there is wide diversity of opinion as to the most effective method of remedying this deficiency. Concepts of the appropriate functions to be assigned to a Consumers' Bureau vary widely.

The organization of the executive branch of the federal government reveals a distinctly dual pattern. The older departments and agencies were established along functional lines. Such departments as State, War, Navy, Treasury, Interior, and Justice simply constitute a convenient division of the necessary activities of government. Each of these departments, in the performance of its functions, is supposed to represent the citizens of the nation as a whole.

The complexity of modern life forced a recognition-express or implied-that no single group of administrative officials is capable of considering all phases of the public interest simultaneously. Accordingly, new departments were established to represent the specific interests of major economic groups; Agriculture for the farmer, Commerce for the businessman, and Labor for the worker.

Thus far, the consumer has not been accorded similar recognition. This is not at all surprising. It is only very recently that the distinctive nature of the consumer interest has come to be clearly understood and that its representatives have become articulate.

Confusion of the consumer interest with the general public interest and easy truisms such as "we are all consumers," constituted basic difficulties. The specific

\footnotetext{
- B.S., 1920, College of the City of New York; S.B. (Electrochem. Eng.), I922, Massachusetts Institute of Technology. Senior Economist, Bureau of Labor Statisties, U. S. Department of Labor. In charge of preparing an analysis of the function of a State Consumers' Department for the N. Y. State Constitutional Convention Committee, 1937-1938. Author: Minimum Price Legislation Under Codes of Fair Competition (1936); co-author: Business Under the New Price Laws (1937); contributor to Harper's Magazine on conomic subjects.
} 
nature of the farmer interest, the labor interest, and the business interest is immediately apparent. Each constitutes a vertical division of the national economy; each comprises a numerous group of distinct individuals. The consumer interest, on the other hand, constitutes a horizontal division cutting acrosis the entire population. It comprises a specific function-the buying function-rather than a specific group of people. As a result, the consumer interest is diffuse compared with the other interests mentioned; it is harder to segregate and far more difficult to organize for its own protection. ${ }^{1}$

The difficulty of organizing the consumer interest effectively is increased by the fact that each individual, in addition to his function as a consumer, usually has some other specific role in the economic field; he may be a worker, or a farmer, or a manufacturer, or a retailer. For the average man, this special interest psychologically overshadows his broader general interest as a consumer. Consequently, the consumer movement has been forced to depend largely upon the activities of those for whom this psychological conflict is less apparent, and for whom the buying role assumes greater weight, such as women, salaried workers, and, on a restricted sector, purchasing agents.

Nevertheless, the past five years have witnessed a multiplication, within the federal government, of activities more or less closely related to the welfare of the consumer. This trend does not reflect any express or clearly formulated policy of according parity to the consumer interest in administrative councils. It springs, rather, from a variety of imperfectly related motives and causes. ${ }^{2}$ As a result, the expansion of consumer activities has been little better than haphazard. It has lacked coordination and has followed no specific direction in thinking or policy. Yet, despite these handicaps, there is rapidly accumulating evidence of its potentialities.

This increased concern of government with the welfare of the consumer has taken two forms. The first is an intensification of established lines of activity, sometimes coupled with a marked reorientation in the thinking and policy of the administrative officials responsible. This has occurred in many agencies whose relationship to the consumer is indirect or incidental to some other primary function. Increased effort to establish commodity standards for the mutual benefit of business and the consumer is a case in point. Greater zeal and efficiency is also noticeable in more specifically consumer-centered activities along lines which have long been considered appropriate functions of government, such as protection of the public health and the prevention of gross fraud and deceit.

\footnotetext{
${ }^{1}$ For an excellent analysis of the nature of the consumer interest, prepared by Gardiner C. Means, see The Consumer and the New Deal (May, I934) r73 Annuxs As. Acso. Pol. \& Soc. Science, 7.

2 Among these may be: (I) The disturbing disparity between purchasing power and producing capacity; (2) The increase in the power and scope of administrative tribunals; (3) The multiplication of economic legislation affecting the consumer; (4) Government experiments with price-fixing; (5) Realization of the need for placing.some restraint upon pressure groups representing sellers; (6) Accumulated evidence of the limited effectiveness of existing laws prohibiting misrepresentation and deception; (7) The possibility of conducting studies into problems of consumer interest as "white collar" relief projects; (8) Increasing activity of women's organizations; (9) Increasing activity of professional organizations of public and private purchasing agents.
} 
More significant, however, of the newly developing relationship of government and the consumer, is the establishment of agencies specifically instructed to represent the consumer interest before regulatory bodies. The Consumers' Advisory Board of NRA and the Consumers' Counsels of the National Emergency Council, of the $\mathrm{AAA}$, and of the Bituminous Coal Commission, constitute distinct innovations in political philosophy. Fortunately, the men in charge of these new offices have generally adopted a very comprehensive interpretation of the scope of their functions. As a result, recent experience permits an appraisal of the possible future relationship of the federal government and the consumer interest.

\section{Misrepresentation and Deception}

A time-honored form of government activity is the prevention of outright misrepresentation and deception in the sale of goods. The principal federal agencies engaged in this work have been the Food and Drug Administration and the Federal Trade Commission. The former has been handicapped by deficiencies in the Act it administered, and the latter by the fact that the primary purpose of its statute was the protection of business competitors rather than of consumers. ${ }^{3}$ The recent Food, Drug and Cosmetic Act and the Wheeler-Lea Act, discussed elsewhere in this symposium, have materially reduced these obstacles, though there is some question as to the desirability of the procedural changes embodied in the latter.

But though machinery may be adequate to cope with outright deceit in advertising, ${ }^{4}$ prohibiting lies is only half a solution unless a standard of truth is established simultaneously. The consumer wants not only less misinformation but also more true information. The odd notion is growing that he has the right to know precisely what kind of commodity it is that he is buying.

The new Food and Drug Act has imposed a number of specific requirements with respect to information that must appear on the labels of the products subject to it. The power which was granted in I930 to establish standards of quality for canned foods has, now been extended to cover virtually all food products. Both that $A C t^{5}$ and the Wheeler-Lea $A c t^{6}$ contain the following important declaration of Congressional policy which, if sympathetically interpreted by the courts, ${ }^{7}$ should go far toward protecting the consumer against deceptive half-truths:

"... in determining whether any advertisement is misleading there shall be taken into account ... not only misrepresentations made or suggested ... but also the extent to

\footnotetext{
'Thus, in the famous Raladam decision, the Supreme Court forbade the Commission to restrain the maker of an obesity cure because the evidence showed injury only to the public, not to competitors. The Court speculated whether Congress had legislated "for the purpose of preserving the business of one knave against another." Federal Trade Comm'n v. Raladam Co., 283 U. S. 643 (I93I). The consumer had no recourse against either knave.

"In the Federal Trade Commission, a special Board of Investigation, (now a Division) has been engaged in examining printed and radio advertising for objectionable matter for many years. During 1937 it examined more than 130,000 printed advertisements and almost half a million radio scripts.

${ }^{B}$ Food, Drug, \& Cosmetic Act, \$201 (n), 21 U. S. C. A. \$30I(n) (Supp. 1938).

'FTC Act, \$15(a), 15 U. S. C. A. \$55(a) (Supp. I938).

7 The attitude of the courts toward misrepresentation is growing stricter. In Federal Trade Comm'n v. Standard Education Society, 302 U. S: I12 (1937), the Supreme Court in upholding the Commission's
} 
which the advertisement fails to reveal facts material in the light of such representations. ...."

The Federal Trade Commission's current drive to require that textile fabrics be accurately labeled as to fiber content is particularly interesting. In its course, the Commission has apparently modified its trade practice conference procedure significantly. It seems no longer content with merely ratifying or revising the rules proposed by industry; instead it takes active steps to shape them to safeguard the consumer interest.

Thus, the Commission flatly rejected the rules originally submitted by the rayon industry as "not acceptable." It then proceeded to formulate its own set of rules designed to protect the consumer more adequately. This new set was issued as "tentatively approved"; interested parties were afforded an opportunity "to present their views for the information and consideration of the Commission before it proceeds to its final decision." - possibly a majority-objected vigorously, the Commission formally promulgated rules substantially the same as those which it had itself formulated. This technique, should it survive court tests, permits a substantial widening of the Commission's sphere of effective action. ${ }^{9}$

Yet the establishment of quality standards and rules of identification for commodities as well as other forms of informative labeling is retarded materially by the degree of its dependence upon the cooperation of business; in many lines this has not been extended. The development of commercial standards by the Bureau of Standards must wait upon the initiative of industry. Food manufacturers have shown little eagerness to adopt the quality grades established by the Bureau of Agricultural Economics for many kinds of foodstuffs. The effort to make quality grades mandatory as to canned goods under NRA was fought by the large canners with a flood of propaganda as illogical as it was vigorous. ${ }^{10}$

\section{Research}

A second long-accepted field of government activity is research. Adequate research is a necessary basis for intelligent action in any field. The furtherance of the consumer interest requires study in many fields; legal, technical, and economic.

order, rejected a defense based on the proposition that the statement complained of was obviously false and hence not deceptive, stating, at p. II6: "The fact that a false statement may be obviously false to those who are trained and experienced does not change its character nor take away its power to deceive others less experienced. There is no duty resting upon a citizen to suspect the honesty of those with whom he does business. Laws are made to protect the trusting as well as the suspicious." The Circuit Court of Appeals had manifested a strikingly different attitude in its decision which was reversed. See 86 F. (2d) $692,695-696(1936)$.

${ }^{8}$ See FTC Press Releases, Sept. I7 and 27, 1937.

- Some manufacturers questioned the validity of the entire proceeding on the ground that trade practice conferences were a mutual, not a unilateral, undertaking. The Commission, however, regards the rules as merely detailed restatements of the existing law. So far, they seem to have been generally observed.

${ }^{10}$ For the story of this interesting episode, see Mulford, Information Concerning Commodities-A Study in NRA and Related Experience in Control, Part B: Standards and Labeling, Worx Materuals, No. 38, NRA Division of Review (1936) 134-I52. 
In the field of legal research, the Consumers' Project ${ }^{11}$ has prepared many valuable compilations. It has published analyses of federal legislation affecting consumers, of federal and state commodity standards and of statutes and decisions concerning consumers' cooperatives.

Technical commodity research is being conducted in many fields. Thus quality improvement studies have been undertaken by the Bureau of Fisheries. The Bureau of Standards assists business-and incidentally the consumer-by cooperating in the establishment of industrial standards and specifications. The Bureau of Agricultural Economics develops standards for agricultural products. More specifically concerned with the welfare of the consumer is the Bureau of Home Economics. Among its other functions, it studies the consumption value of many kinds of goods; the nutritive value of various foods, the utility of different fabrics, and the performance results of household equipment. The Consumers' Project has assembled what is probably the most complete collection of purchasing specifications for consumer goods ever compiled.

Much economic research, too, has been devoted to problems affecting the consumer. The investigations into competitive problems conducted by such agencies as the Federal Trade Commission, for example, have thrown light upon many questions in which the consumer is vitally interested. The same may be said of many of the studies made by the Tariff Commission, the Bureau of Agricultural Economics, the Bureau of Foreign and Domestic Commerce, and the Division of Review of NRA. Marketing problems of primary consumer interest have been the subject of research by the Consumers' Counsels of AAA and of the Bituminous Coal Commission. A particularly ambitious analysis of consumer purchases and incomes under the joint auspices of the Bureau of Labor Statistics, the National Resources Committee, and the Bureau of Home Economics, is just drawing to a close. The current "monopoly" study will undoubtedly touch upon many questions of major importance to the consumer. ${ }^{12}$

But if there is no lack of research activity, there is crying need for coordination and interpretation. The results of most of these studies have been compiled in ponderous and imposing monographs, prefaced with appropriate letters of transmittal to Congress or to the President, and promptly forgotten by all save a few specialists. Moreover, information has been compiled from so many sources and is scattered through so many reports that it is virtually impossible, even for the wellinformed consumer, to glean a connected study relating to any single issue.

\footnotetext{
${ }^{21}$ This office is an offshoot of the Consumers' Advisory Board of NRA which, after being temporarily assigned to the Department of Labor, has recently been transferred to the Consumers' Counsel of AAA as a WPA project.

Is One important omission is the failure to conduct a comprehensive survey of marketing practices, involving an examination of the relative efficiency of competing channels of distribution and the effects of such legislation as the so-called "fair trade" laws and the chain store taxes. Even in this field, a project had been planned and actually begun, but was later abandoned.
} 


\section{Representation of the Consumer Interest}

Work done by federal agencies along the lines just discussed, important as it is to the welfare of the consumer, represents merely a more active or more effective performance of long-accepted functions. On the other hand, the establishment of offices charged with the specific duty of representing the consumer interest constitutes a distinct political innovation.

It has long been apparent, to careful observers, that something was amiss in the proceedings of our regulatory administrative offices. For example, when the Interstate Commerce Commission was established, it was expected to play a dual role. On the one hand, it was supposed to bring order to a distracted industry and to establish a rate structure fair alike to railroads and to shippers. At the same time, it was hoped that it would militantly protect the consumer interest-which was generally assumed to be synonymous with the public interest-against the claims of both roads and shippers.

As time went on, the Commission increasingly emphasized its judicial function at the expense of its role as public defender. In the light of present analysis, this tendency appears to have been inevitable. It could not simultaneously perform two incompatible functions. The interest of the consumer in low rates is as much a special interest as is the desire of the roads for higher profits. It is obviously impossible for the same group of officials to act as impartial arbiters and as zealous defenders of one of the parties involved. Nor could the shippers adequately present the case for the consumer; their problems were far more special than were those of the far broader, though still partisan, consumer interest. As a result, the latter has been largely unrepresented at court and has lacked an effective voice in the Commission's deliberations.

Recognition of the need for a consumers' advocate before tribunals of this sort was slow to come. The first clear-cut effort in this direction came in 1930, with a proposal to provide for a consumers' counsel to the Tariff Commission. But the need for such action was not yet clearly understood and it remained for some of the New Deal agencies to put the idea into practice.

The first official representation of the consumer interest was concurrent with the enormous expansion of federal regulatory functions under NRA and AAA. The history of the Consumers' Advisory Board of NRA was brief, but interesting. In theory, this board was accorded parity with the Advisory Boards representing Industry and Labor. In practice, however, it faced an arduous uphill struggle before it succeeded in achieving any effective voice in NRA policy.

For the first six months of NRA, during which period the codes for the largest sectors of industry were written, the Consumers' Board was largely a voice crying in the wilderness. Administrative officials almost unanimously ignored its representations. The struggle between labor and industry to shape the wage and hour provisions of the codes occupied the center of the stage. Price-fixing and production- 
control provisions were held out as bait to induce industries to grant concessions on the labor front. 'The protests of the Consumers' Board were usually disregarded.

As code making was succeeded by code administration, responsible officials began to recognize the validity of many of the objections which had been so brusquely overruled. The wide and unwarranted increases in price which occurred under the codes brought increasing protests from consumers and from many industry members. Difficulties of administering price-fixing provisions became apparent. As a result, policy veered more and more toward the position which the Consumers' Board had consistently held. NRA amended many of the more drastic price-fixing provisions contained in the codes; enforcement of the others was less than perfunctory. An Advisory Council was created to pass upon questions of policy; in this Council the Board was granted a full and effective voice. Just before the Schechter decision, plans had been laid for a general revision of the codes which would have incorporated many of the major recommendations of the Consumers' Advisory Board.

A similar struggle confronted the Consumers' Counsel of AAA during this period. During June, I933, Secretary Wallace suggested to Administrator Peek that a unit be established to represent the consumer. He referred to the fact that two Divisions had already been set up to represent the specific interests of producers and of processors and distributors. He also mentioned the probable future necessity of defending the decisions of AAA before Congress and the public.

A Consumers' Counsel was accordingly appointed. He was ance faced with something of a dilemma in policy determination. The AAA was committed to an endeavor to raise the prices of agricultural products; this was, in fact, the primary object of its creation. The Consumers' Counsel could not consistently oppose a program which was the very heart of the organization of which he was part. $\mathrm{He}$ compromised-perhaps to his own satisfaction-by urging that increases in farm prices be accompanied by provisions designed to achieve greater efficiency in processing and distribution.

Such an objective may be appealing in theory, but it scarcely formed a practical program for effective action. A later Administrator, Chester C. Davis, tried to resolve the conflict in a somewhat different manner. In a public letter, issued April 25, 1935, describing the functions of the Consumers' Counsel, he said in part:

"Its function, so far as the Agricultural Adjustment Administration is concerned, is to represent the interest of the consumer at every stage in the Administration's activities. When a commodity control program, a marketing agreement, or a licensing agreement is under consideration, it is essential that both producers' and consumers' interests be represented by trained economists, highly skilled in research and in the interpretation of economics. In many cases, there is no conflict of interests: the consumer wants the producer to receive the kind of returns for his produce that will insure the continuance of an adequate food supply, and the farmer wants the consumer to be able to buy an adequate volume of farm products. In some cases, where there is some apparent conflict, on particular points, it is the function of the Consumers' Counsel to represent the consumer and assist in finding the point of maximum justice to both producer and consumer. . .." (Italics supplied.) 
Examined carefully, this becomes merely a restatement of the dilemma. The interests of consumers and producers are necessarily opposed in the first instance. Presumably there is some golden mean between the two, but the process of reaching it is one of conflict. Efforts by the Consumers' Counsel to perform his assigned functions were actively resented by farm and business interests. Administrative officials, faced by insistent demands for action and controlled by considerations of expediency, were impatient with what they considered destructive tactics. The diffculties inherent in the situation were reflected by several changes of Consumers' Counsels, and even by a temporary reduction in the status of the office from Division to Section. The Counsel was denied the confidence of administrative officials; sometimes he was apprised of pending action long after any opportunity for effective intercession had passed.

Unfortunately, unlike the experience of the Consumers' Advisory Board, there is no clear evidence yet of any major improvement in the situation. In some of his efforts at protecting the consumer's interest, the Counsel achieved distinct success. The weight given to his opinions by AAA officials seemed, at times, to be increasing. However, any permanent trend must await a specific clarification of his position and authority. It is to be hoped that this will be brought about as part of the current reorganization of the Department of Agriculture.

The only other officially designated agency of-this character is the Consumers' Counsel of the Bituminous Coal Commission. There is one difference of major importance between this office and that of the Consumers' Counsel of AAA. The latter was established by the Administrator of AAA and exists at his pleasure. The former was set up by specific Congressional enactment and is responsible only to the Congress and the President. The Consumers' Counsel is an adviser to, but completely independent of, the Commissioners of the Bituminous Coal Commission. Moreover, the Commission is required by law to furnish the Consumers' Counsel with any statistics or data in its possession which he may need for the proper performance of his function. ${ }^{13}$

The history of this Consumers' Counsel may be divided into two distinct phases. At first, he encountered the same difficulty in obtaining serious consideration for his

25 The statutory provision for this office is quoted in part:

Section 2 (b) (2) It shall be the duty of the counsel to appear in the interest of the consuming public in any proceeding before the Commission and to conduct such independent investigation of matters rclative to the coal industry and the administration of this Act as he may deem necessary to enable him properly to represent the consuming public in any proceeding before the Commission. In any such proceeding be: fore the Commission, the counsel shall have the right to offer any relevant testimony and argument, oral or written, and to examine and cross-examine uvinesses and parties to the proceeding, and shall have the right to subpena or other process of the Commission issue in his behalf. Whenever the counsel finds that it is in the interest of the consuming public to have the Commission furnish any information at its command or conduct any investigation as to any matter within its authority, the counsel shall so certify to the Commission, specifying in the certificate the information or investigation desired. Thereupon the Commission shall promptly furnish to the counsel the information or promptly conduct the investigation and place the results thereof at the disposal of the counsel. . . .

(4) The counsel shall annually make a full report of the activities of his office directly to the Congress. Bituminous Coal Act of 1937, 50 STAT. 72, 15 U. S. C. 5829 . (Italics supplied.) 
comments or criticism as had faced the Consumers' Advisory Board of NRA or the Consumers' Counsel of AAA. The administrative officials of the Commission were inclined to consider his office as entirely superfluous. His efforts to obtain cost data justifying the proposed schedule of minimum prices were entirely unavailing. Possibly this was because no accurate cost data had been collected; the precise level or justification of the prices may have been deemed of little importance. The major effort was to promulgate minimum prices quickly and to yield immediate relief to the industry from the competitive conditions confronting it. The recommendations of the industry were apparently accepted with little review or discrimination; the protests of the Consumers' Counsel ignored or brushed aside.

Inevitably, a court test of the prices promulgated was begun. The decision was a foregone conclusion. ${ }^{14}$ The disregard of the clear injunction of the law and the refusal to accord the protests of the Consumers' Counsel the consideration to which they were entitled, were too patent to stand any test of due process.

With the invalidation of the prices first promulgated, the office of the Consumers' Counsel attained a new importance in the eyes of the Commission. Where his advice had previously been unwelcome and rejected, it is now given weight. The courts pointed out the duty of the Commission to consider the interests of the different economic groups affected by its decisions. The role of the Consumers' Counsel as the officially designated representative of one of these groups is now understood and accepted. There is evidence that his office is now more effectively fulfilling the functions which it was established to perform.

Nor are the activities of the Consumers' Counsel as representative of the consumer interest confined to the deliberations of the Bituminous Coal Commission. He has also appeared, in accordance with the terms of the statute, ${ }^{15}$ before the Interstate Commerce Commission. Although his intervention in rate cases is confined to matters affecting coal, this still constitutes the first official representation of the consumer interest before the Interstate Commerce Commission.

In addition to representing the consumer before administrative bodies, it seems also essential to provide an effective voice for him before Congressional committees. The demands for special legislation from minority pressure groups show no sign of abating. The propaganda machines of trade associations are functioning more and more smoothly. The arguments for special legislation designed to promote the interests of militant economic groups are presented with great skill. In the absence of any effective presentation of the opposing side, it is virtually impossible for the average Congressman to pass intelligent judgment upon the complex economic issues involved. For example, the Robinson-Patman ${ }^{16}$ and Miller-Tydings ${ }^{17}$ Acts have far-reaching effects upon the welfare of the consumer. There is grave doubt that

14 Saxton Coal Mining Co. v. Nat. Bituminous Coal Comm'n, 96 F. (2d) 517 (App. D. C. I938).

15 Bituminous Coal Act of $1937, \$ 16,50$ STat. 90, 15 U. S. C. $\$ 846$.

10 Amending the Clayton Act to provide more rigorous control over price discrimination: 49 Star. (1936), I5 U. S. C. 55 r3, 13a, 13b, $21 a$.

${ }^{27}$ Excepting resale price maintenance contracts, where valid by state law, from the operation of the Sherman Act. 50 StAт. 693 (1937), 15 U. S. C. Sr. 
either of these laws is economically desirable. Yet, the case for both was presented very effectively; the case for the opposition was scarcely even broached.

The seriousness of this lack becomes daily more apparent as the deluge of economic legislation vitally affecting the consumer interest continues. Moreover, existing consumers' agencies are hampered in rendering their limited potential contribution by statutory " provisions prohibiting executive departments from lobbying. Their only permissible activity, which some are exploiting fully, is to assist independent consumer organizations to present their points of view by furnishing them with information and advice. It has proved impossible, however, to maintain any coordinated consumer lobby to offset the activities of business pressure groups.

\section{Promoting Consumer Organizations}

Federal agencies such as these, charged with the duty of protecting the consumer interest, cannot hope to succeed without the militant support of an active and wellorganized consumer movement outside the government. Similarly, the Labor Department would be largely ineffective were it not for the existence of labor unions; the Department of Agriculture without farmers' organizations and the Department of Commerce without trade associations.

The Consumers' Division of the National Emergency Council recognized this principle five years ago. Accordingly, it set about establishing county consumers' councils throughout the country in order to permit the consumer to become articulate; to inform the consumer of what government was doing, and to acquaint government with what consumers were thinking. For a long time these organizations were accorded active government support including the use of office space and even permission to use the postal frank. This last privilege was withdrawn two years ago, but the consumer movement is making important strides upon its own feet. The effective organization of the consumer interest remains a major objective of the two Consumers' Counsels. They cooperate actively with these groups and, in turn, owe much of whatever effectiveness they have attained to their support.

A closely related program is the establishment of Consumers' Bureaus as integral agencies of the governments of the various states. ${ }^{18}$ Here, too, the federal Con. sumers' Counsels are rendering active, if unofficial, support. ${ }^{19}$ They do this with the conviction that the existence of such state bodies will perform an invaluable function in crystallizing consumer sentiment and in increasing the effectiveness of their own efforts.

\section{Consumer Education}

Concurrent with these efforts to increase the political influence of the consumer, is the attempt to increase his economic effectiveness. Various federal agencies are

\footnotetext{
${ }^{18}$ For an analysis of the functions which such state agencies can usefully perform, see $8 \mathrm{~N}$. Y. STATE Constitumonal Convention Conanatree (1938) 424-465 (c. XVIII, "Proposed State Departments: Consumers").

${ }^{20}$ The Consumers' Counsel of the Coal Commission was influential in the establishment of a Consumers' Bureau in Michigan, a body created by executive order of Gov. Frank Murphy.
} 
endeavoring to render available to the consumer information which will permit him to expend his purchasing dollar more efficiently. Reference has already been made to the work of such agencies as the Bureau of Agricultural Economics. A wealth of material has been compiled which can assist the consumer to plan his purchases wisely and discriminately. Unfortunately, most of this information is contained in publications whose circulation is at best limited.

The most conspicuous effort to distribute such matter widely, and in readable and readily understandable form, is the Consumers' Guide. This periodical has been published for five years by the Consumers' Counsel of AAA. It has recently attained its maximum permissible circulation of $135,000 .{ }^{20}$ It presents analyses of the value and use of many important consumer goods. Moreover, it has included simple and lucid discussions of many general problems of consumer interest, such as marketing practices and current legislative provisions. For example, a recent issue (June 6, 1938) carried a concise exposition of the significance of the Wheeler-Lea Act to the consumer and of Federal Trade Commission procedure in its administration.

The same office has attempted to widen its contact with the consuming public by a regular weekly broadcast. Moreover, it receives and answers some 28,000 letters annually from individual consumers seeking specific information.

In its own special field, the Consumers' Counsel of the Bituminous Coal Commission has been conducting a similar program. It issues publications designed to inform the consumer of the salient points to consider in purchasing bituminous coal. It has endeavored, with some apparent success, to persuade producers of the desirability of labeling coal as to heat value and ash content. It is preparing a study series for colleges and universities covering the general field of administrative price regulation.

\section{Summary and Appraisal}

The foregoing survey is necessarily brief and incomplete. ${ }^{21}$ It is apparent, however, that federal activities designed to benefit the consumer directly or indirectly are proceeding with varying degrees of effectiveness on many scattered fronts. The sheer diversity and volume of these efforts is impressive.

Nor is the conduct of these various activities subject to any generally valid criticism. Many of them are well staffed and competently directed. It is true that some are seriously hampered for lack of adequate funds, and that the attitude of certain administrative officials constitutes a barrier to the success of others. But these difficulties are incidental. The fundamental reasons for the failure of the consumer to achieve the degree of protection necessary for his well-being and the economic health of the nation lies elsewhere.

The first is the lack of any comprehensive machinery for planning or coordination. On the one hand, there is much duplication of effort; on the other, many im-

so Budgetary limitations preclude its further expansion at this time, despite a waiting list of more than 10,000 potential subscribers.

II For a more comprehensive listing, see Consumer Services of Government Agencies (Consumers' Counsel, AAA). 
portant fields remain largely untouched. It seems unfortunate that the two fields in which Consumers' Counsels are now functioning-Agriculture and Bituminous Coal-are precisely those in which most informed observers believe current prices to be too low.

The second major shortcoming of the present scheme is the dependent status of most of the agencies involved. It is obvious that the job of promoting the consumer interest should not be entrusted solely to subordinate bureaus or divisions of departments whose primary responsibility is to some other economic interest, such as labor, the farmer, or business. Nor can quasi-judicial agencies properly be expected to perform this basically partisan function.

There have been suggestions that these two requirements of coordination and independence could be achieved through the establishment of a new Department of the Consumer. This scheme contemplates the wholesale transfer of all consumer protective activities currently being conducted to such a new Department. The head of this Department would be accorded cabinet status, thereby granting to a representative of the consumer interest parity with the Secretaries of Agriculture, Labor, and Commerce.

Conceivably this proposal may constitute an ultimate goal; it is not an immediate practical possibility. Congress may establish a new Department of Public Welfare, but there is no chance that it would simultaneously authorize two new departments. Moreover, any attempt to combine most activities affecting consumers under a single ægis would encounter seriols physical difficulties and might result in confusion and inefficiency.

Even the centralization of purely protective functions, such as those performed by the Consumers' Counsel, would incur a penalty. It would preclude the intimate contact essential between the representative of the consumer interest and the administrative agency with whose affairs he is concerned. If AAA officials now take no great pains to keep their Consumers' Counsel abreast of proposed decisions, it is unlikely that they would cooperate any more actively with a totally distinct Department.

The immediate need is not centralization, but coordination. A long step forward would be the establishment of an independent Consumers' Bureau, possibly under the proposed Department of Public Welfare. Such a Bureau would act as a center or focus for federal consumer activities. Recognizing that the consumer himself is the only effective guardian of his own interests, it would devote a major share of effort toward fostering the growth of consumer organizations. Moreover, since it is manifestly impossible for any group of officials in Washington to keep abreast of consumer developments throughout the nation, every effort would be made to hasten the establishment of consumers' bureaus or departments within each state government. The federal bureau would constitute an established point of contact between organized consumer groups, state consumer agencies and the national government. A comprehensive program of consumer education would go hand in hand with 
these efforts to promote his effective organization. Much of the spadework has already been done. The work currently performed by the two Consumers' Counsels furnishes an excellent pattern. The Bureau would issue a regular publication explaining matters of general consumer interest; prepare special reports discussing selected problems in more detail; conduct weekly radio programs and cooperate with educational institutions in planning courses of study. Nor would this preclude a continuation of much of the work now being done under other auspices. Information regarding coal, for example, could still be disseminated by the Coal Consumers' Counsel, though he would undoubtedly consult with the Bureau to promote coordination and avoid duplication.

Naturally, the Bureau would have access to information compiled by other government agencies. It would actively seek to expand the available fund of such information on matters of consumer interest. It might do so partly by conducting research programs of its own. At least at first, however, such programs should, in all probability, be limited in scope. Its efforts could most profitably be utilized in giving focus and direction to the work of existing research agencies through conference and consultation. It might concentrate largely upon coordinating the mass of data collected by these other agencies, upon interpreting it in its relation to the consumer's welfare, and upon presenting it in elementary, concise, and graphic terms stripped of technical phraseology.

A similar approach might be adopted toward the development of commodity grades and standards. It would be absurd to attempt to duplicate the elabörate facilities available in, say, the Bureau of Standards. On the other hand, the new Bureau could perform a very useful function by acquainting consumers with established rules and standards, and actively promoting the adoption of new ones by crystallizing consumer sentiment and by urging business and government agencies to cooperate in the effort.

Nor would its role as the officially designated guardian of the consumer interest necessarily be exclusive. It would, of course, represent the consumer before those agencies which are not specifically provided with a consumers' advocate. On the other hand, the Consumers' Counsel of the Coal Commission may be in far better position to act quickly and effectively upon matters related to coal regulation than a Consumers' Bureau with more general functions. ${ }^{22}$ Similarly in the case of the AAA, the Consumers' Counsel should be made independent of the administrative organization but not removed from direct contact with it. ${ }^{23}$

More broadly, the new Bureau would be expected to maintain a general watch

Moreover, the present statutory provision endows this office with more authority than would be probable under any other arrangement.

The precise relationship between the new agency and Consumers' Counsels accredited to specific agencies is a subject of some controversy. Three alternatives seem possible:

(I) The tie might be merely one of a common interest, involving mutual consultation and cooperation, but no administrative link.

(2) The specific Consumers' Counsels might be appointed by the head of the new Bureau, placed 
over political and economic events and to appraise their relationship to the consumer. Its advice would be available to Congress upon pending legislation. It might appear, officially or unofficially, as "amicus" before administrative tribunals. ${ }^{24}$

All these are, of course, no more than guesses. It is impossible, in advance, to chart a definite course for a new agency of government and particularly for one representing a distinct departure in political philosophy. The basic present need is the establishment of such an independent agency dedicated to the furtherance of the consumer interest. Experience alone will determine the manner in which it can most usefully operate. However, the general lines seem reasonably clear. It will coordinate rather than centralize; advise rather than direct; and educate rather than legislate. And, in so doing, it should contribute materially to the well-being of the consumer and to the stability of the general economy.

upon his pay roll and subjected to his supervision. They would maintain offices at the agencies to which they were accredited, but would be responsible exclusively to the new Bureau.

(3) A compromise might be adopted under which, say, the Secretary of Agriculture would appoint a Consumers' Counsel upon nomination by the head of the new Burcau.

${ }^{24}$ It might also appear at hearings held by administrative agencies in the formulation of regulations, as, for example, under the new Food, Drug, and Cosmetic Act. 